Prepared in cooperation with the U.S. Fish and Wildlife Service and the Red Lake Watershed District

\title{
Mercury in Wetlands at the Glacial Ridge National Wildlife Refuge, Northwestern Minnesota, 2007-9
}

Scientific Investigations Report 2013-5068 
Cover. An ephemeral wetland after the spring melt, Glacial Ridge National Wildlife Refuge, northwestern Minnesota, April 2011. 


\section{Mercury in Wetlands at the Glacial Ridge National Wildlife Refuge, Northwestern Minnesota, 2007-9}

By Timothy K. Cowdery and Mark E. Brigham

Prepared in cooperation with the U.S. Fish and Wildlife Service and the

Red Lake Watershed District

Scientific Investigations Report 2013-5068 


\title{
U.S. Department of the Interior SALLY JEWELL, Secretary
}

\section{U.S. Geological Survey Suzette M. Kimball, Acting Director}

\author{
U.S. Geological Survey, Reston, Virginia: 2013
}

For more information on the USGS - the Federal source for science about the Earth, its natural and living resources, natural hazards, and the environment, visit http://www.usgs.gov or call 1-888-ASK-USGS.

For an overview of USGS information products, including maps, imagery, and publications, visit http://www.usgs.gov/pubprod

To order this and other USGS information products, visit http://store.usgs.gov

Any use of trade, firm, or product names is for descriptive purposes only and does not imply endorsement by the U.S. Government.

Although this information product, for the most part, is in the public domain, it also may contain copyrighted materials as noted in the text. Permission to reproduce copyrighted items must be secured from the copyright owner.

Suggested citation:

Cowdery, T.K., and Brigham, M.E., 2013, Mercury in wetlands at the Glacial Ridge National Wildlife Refuge, northwestern Minnesota, 2007-9: U.S. Geological Survey Scientific Investigations Report 2013-5068, 17 p., http://pubs.usgs.gov/sir/2013/5068/. 


\section{Contents}

Abstract
Introduction
Objectives, Study Design, and Methods
Wetland Water Quality
Mercury in Wetlands
Sethylmercury in Water and Its Relevance to Aquatic Ecosystems

\section{Figures}

1. Map showing Glacial Ridge National Wildlife Refuge area, northwestern Minnesota

2. Map showing sampled wetlands and sampling sites, Glacial Ridge National Wildlife Refuge, northwestern Minnesota, 2007-9....

3. Piper (trilinear) diagram showing wetland water ionic composition, Glacial Ridge National Wildlife Refuge, northwestern Minnesota, 2007-9..........................................9

4. Boxplot showing wetland water nutrient composition statistics, Glacial Ridge National Wildlife Refuge, northwestern Minnesota, 2007-9.

5. Boxplots showing wetland water mercury concentrations, Glacial Ridge National Wildlife Refuge, northwestern Minnesota, 2007-9

6. Boxplots showing wetland sediment mercury concentrations, Glacial Ridge National Wildlife Refuge, northwestern Minnesota, 2007-9.

\section{Tables}

1. Comparison of planned sampling design with collected samples, Glacial Ridge National Wildlife Refuge, northwestern Minnesota, 2007-9.

2. Water-quality sampling details and constituents analyzed, Glacial Ridge National Wildlife Refuge, northwestern Minnesota, 2007-9.

3. Water-quality and sediment-quality data collection sites, Glacial Ridge National Wildlife Refuge, northwestern Minnesota, 2007-9

4. Chemicals with blank-sample concentrations greater than the laboratory reporting level. 


\title{
Conversion Factors
}

\begin{tabular}{|c|c|c|}
\hline Multiply & By & To obtain \\
\hline \multicolumn{3}{|c|}{ Length } \\
\hline inch (in.) & 2.54 & centimeter $(\mathrm{cm})$ \\
\hline mile (mi) & 1.609 & kilometer $(\mathrm{km})$ \\
\hline \multicolumn{3}{|c|}{ Area } \\
\hline acre & 0.4047 & hectare (ha) \\
\hline \multicolumn{3}{|c|}{ Volume } \\
\hline quart (qt) & 0.9464 & liter $(\mathrm{L})$ \\
\hline \multicolumn{3}{|c|}{ Mass } \\
\hline ounce, avoirdupois (oz) & 28.35 & $\operatorname{gram}(\mathrm{g})$ \\
\hline
\end{tabular}

Vertical coordinate information is referenced to the North American Vertical Datum of 1988 (NAVD 88).

Horizontal coordinate information is referenced to the North American Datum of 1983 (NAD 83).

Elevation, as used in this report, refers to distance above the vertical datum.

Concentrations of chemical constituents in water in this report are given in milligrams per liter $(\mathrm{mg} / \mathrm{L})$ or nanograms per liter ( $\mathrm{ng} / \mathrm{L})$. Concentrations of chemical constituents in sediment in this report are given in nanograms per gram $(\mathrm{ng} / \mathrm{g})$.

Water year (WY) is the 12-month period, October 1 through September 30, and is designated by the calendar year in which it ends. Thus, the water year ending September 30, 2009, is called the "2009" water year.

\section{Units of Measure, Abbreviations, and Acronyms}

\author{
$\mathrm{mg} / \mathrm{kg} \quad$ milligrams per kilogram \\ $\mathrm{mg} / \mathrm{L} \quad$ milligrams per liter \\ $\mu \mathrm{g} \mathrm{Hg} / \mathrm{g}$ micrograms mercury per gram \\ $\mathrm{ng} / \mathrm{g} \quad$ nanograms per gram \\ $\mathrm{ng} / \mathrm{L} \quad$ nanograms per liter \\ $\mathrm{N} \quad$ nitrogen \\ NAWQA National Water-Quality Assessment Program \\ NWR National Wildlife Refuge \\ P phosphorus \\ RPD relative percent difference \\ USGS U.S. Geological Survey
}




\title{
Mercury in Wetlands at the Glacial Ridge National Wildlife Refuge, Northwestern Minnesota, 2007-9
}

\author{
By Timothy K. Cowdery and Mark E. Brigham
}

\section{Abstract}

The Glacial Ridge National Wildlife Refuge was established in 2004 on land in northwestern Minnesota that had previously undergone extensive wetland and prairie restorations. About 7,000 acres of drained wetlands were restored to their original hydrologic function and aquatic ecosystem. During 2007-9, the U.S. Geological Survey, in cooperation with the U.S. Fish and Wildlife Service and the Red Lake Watershed District, analyzed mercury concentrations in wetland water and sediment to evaluate the effect of wetland restoration on mercury methylation. The wetland waters sampled generally were of the calcium/magnesium bicarbonate type. Nitrogen in water was mostly in the form of dissolved-organic nitrogen, with very low dissolved-nitrate and dissolved-ammonia concentrations. About 71 percent of all phosphorus in water was dissolved, with one-half of that in the form of orthophosphorus. Wetland water had total-mercury and methylmercury concentrations ranging from 1.5 to 20 nanograms per liter $(\mathrm{ng} / \mathrm{L})$ and 0.2 to $16 \mathrm{ng} / \mathrm{L}$, respectively. Median concentrations were 7.1 and $2.9 \mathrm{ng} / \mathrm{L}$, respectively. About one-half of the mercury in wetland water samples was in the form of methylmercury, but this form ranged from 7 to 81 percent of each sample.

Compared to concentrations in stream sediment samples collected throughout the United States, Glacial Ridge National Wildlife Refuge wetland sediment samples contained typical total-mercury concentrations, but methylmercury concentrations were nearly twice as high. The maximum concentration measured in Glacial Ridge National Wildlife Refuge wetland water approached the highest published water methylmercury concentration in uncontaminated waters of which we are aware. However, the upper quartile of water methylmercury concentrations is similar to concentrations reported for some impoundments and wetlands in northwestern Minnesota and North Dakota. Methylmercury concentrations in sampled wetlands were much higher than those from typical lakes or flowing streams throughout the United States.

The high concentrations of methylmercury measured in sampled wetlands indicate the potential for substantial methylmercury concentrations in aquatic biota and wildlife that consume those biota. These wetlands also are a methylmercury source for downstream lakes and rivers. The high concentrations of methylmercury in water, its bioaccumulation potential, and its known toxicity in aquatic birds and food webs highlight a need to assess methylmercury in the biota within these ecosystems. Better understanding of factors that control methylmercury production concentrations within aquatic food webs in ecosystems of the Glacial Ridge National Wildlife Refuge would enable resource managers to better understand and manage risk to wildlife.

\section{Introduction}

The Glacial Ridge National Wildlife Refuge (hereinafter Glacial Ridge) is located in northwestern Minnesota, about 15 miles east of the city of Crookston (fig. 1). It was established in 2004 on land that had previously undergone extensive wetland and prairie restorations by The Nature Conservancy (The Nature Conservancy, 2012). In total, 7,000 acres of drained wetlands were restored to their original hydrologic function and aquatic ecosystem. In most cases, these wetlands had been drained since the early part of the 20 th century and were used as grazing or crop land. Flooding of terrestrial environments substantially increases methylmercury production and concentrations in physical and biological components of aquatic ecosystems (Bodaly and others, 1997; Kelly and others, 1997; Snodgrass and others, 2000; St. Louis and others, 2004; Strange and Bodaly, 1999). Researchers have seen this phenomenon in nearly every setting in which mercury has been studied, including large hydroelectric reservoirs (Hecky and others, 1991); small impoundments (Bodaly and Fudge, 1999; Brigham and others, 2002; St. Louis and others, 2004); and waters that undergo large changes in stage (long hydroperiod), resulting in periodic drying and reflooding of soils (Snodgrass and others, 2000). These environments contain abundant organic matter, which is a mercury reservoir, and frequently experience anaerobic conditions that promote the growth of mercury-methylating sulfate- and iron-reducing bacteria.

Land managers in the Glacial Ridge area need to understand the dynamics of mercury methylation in the newly restored wetlands to properly manage wildlife populations. To address this need, the U.S. Geological Survey (USGS), in 
cooperation with the U.S. Fish and Wildlife Service and the Red Lake Watershed District, completed a study of mercury in wetlands at Glacial Ridge during 2007-9. This report documents total-mercury (all forms of mercury) and methylmercury concentrations in water and sediment samples from pairs of example wetlands at Glacial Ridge collected for this study. Although water and sediment mercury concentrations are not direct measures of risk to wildlife, these surrogates are relatively easy media to measure and are comparable to many literature measurements. These data provide insights on the relative abundance of methylmercury in Glacial Ridge wetlands compared to other aquatic ecosystems.

Methylmercury production (the conversion of inorganic mercury to the bioaccumulative methylmercury form) at Glacial Ridge is of particular concern because although the land supports a variety of wildlife, primarily birds rely on the aquatic ecosystem to provide food and a habitat in which to raise their young. Fish, birds, and other wildlife are susceptible to the toxic effects of methylmercury, even within the range of concentrations observed in natural settings that are unaffected by direct point-source discharges of mercury waste (Scheuhammer and others, 2012). A recent literature review noted that "correlations indicative of adverse effects in wild fishes have been reported for multiple recent field studies in which maximal tissue concentrations were less than 1.0 micrograms mercury per gram $(\mu \mathrm{g} \mathrm{Hg} / \mathrm{g}$ ) wet weight" (Sandheinrich and Wiener, 2011). Waters with mean aqueous methylmercury concentrations higher than about 0.3 nanograms per liter (ng/L) commonly contain predatory game fish with tissue methylmercury concentrations of about $1 \mu \mathrm{g} \mathrm{Hg} / \mathrm{g}$ wet weight (Chasar and others 2009; Wiener and others, 2006).

Another recent literature review (Scheuhammer and others, 2007) noted that methylmercury concentrations exceeding 15 milligrams per kilogram (mg/kg; parts per million) in tissues of adult birds were associated with methylmercury intoxication, including death. Egg mercury concentrations exceeding $1 \mathrm{mg} / \mathrm{kg}$ are associated with reduced reproductive success (reduced hatchability and increased embryonic mortality) in several bird species, and brain mercury concentrations exceeding $3 \mathrm{mg} / \mathrm{kg}$ are associated with mortality in developing bird embryos (Scheuhammer and others, 2007). Common loons consuming prey that contains more than $0.3 \mathrm{mg} / \mathrm{kg}$ methylmercury suffer reduced reproductive success (Scheuhammer and others, 2007). Heinz and others (2009) examined methylmercury toxicity to the embryos of 26 bird species and found considerable differences in toxicity among species.

Many interrelated dynamic features of natural water bodies cause methylation of inorganic mercury. Mercury methylation is one of many biogeochemical effects caused by hydrologic change in an ecosystem. Organic matter decomposition is an important biogeochemical process in newly flooded (or newly reflooded) wetlands. After inundation, oxygen in sediment pore water (and to an extent the overlying water column) is quickly consumed, and anoxic microbial processes become important, particularly in stagnant water and in the uppermost bed sediments. Some microbes, notably some species of sulfate-reducing bacteria (Compeau and Bartha, 1985) and iron-reducing bacteria (Kerin and others, 2006), produce methylmercury from inorganic mercury as a byproduct of respiration. Over time, mercury methylation may be limited by sulfate depletion or a buildup of reduced sulfur species like sulfide. Reduced sulfur species may effectively complex inorganic mercury, reducing its availability to sulfate-reducing bacteria. In environments that undergo wet/dry cycles, reduced sulfur species may oxidize during dry periods, producing sulfate that is then available for sulfate reduction and mercury methylation during the next wet cycle.

This methylation research indicates that restoring wetlands may result in high rates of mercury methylation and higher methylmercury concentrations than older, established wetlands where the water levels are relatively stable. The magnitude of methylation and its transport to aquatic food webs likely depend on many site-specific and time-varying factors, including hydroclimatic conditions, wetland hydroperiod (how much the stage fluctuates in response to wet/dry cycles), organic-matter content of the flooded soils, nutrient dynamics, and sulfate availability (Bodaly and others, 1997; Pickhardt and others, 2002; Wiener and others, 2003).

This study was undertaken cooperatively between the U.S. Geological Survey and the U.S. Fish and Wildlife Service and the Red Lake Watershed District (Agreement No. 301817J119). Staff from these organizations and The Nature Conservancy provided valuable insights and help. Jason Eckstein, formerly of The Nature Conservancy, provided essential information on wetland hydrologic behavior and restoration history and planning.

\section{Objectives, Study Design, and Methods}

The original objectives of the study were threefold:

1. Determine if and to what degree mercury concentrations in a newly reestablished wetland increase relative to an unrestored wetland,

2. Document mercury concentrations in water and sediment of the wetlands to increase understanding of the potential for high methylmercury exposures to wetland-dependent wildlife, and

3. Compare these mercury concentrations to existing toxicological risk data to underscore its relevance to aquatic ecosystems.

The planned sampling design to achieve these objectives consisted of collecting 24 water and 24 sediment samples per water year for 3 years at four sites established in each of two wetlands. A water year is the 12-month period, October 1 through September 30, and is designated by the calendar year in which it ends. Four sites in each wetland were sampled to assess spatial variability in the wetland water and sediments. 

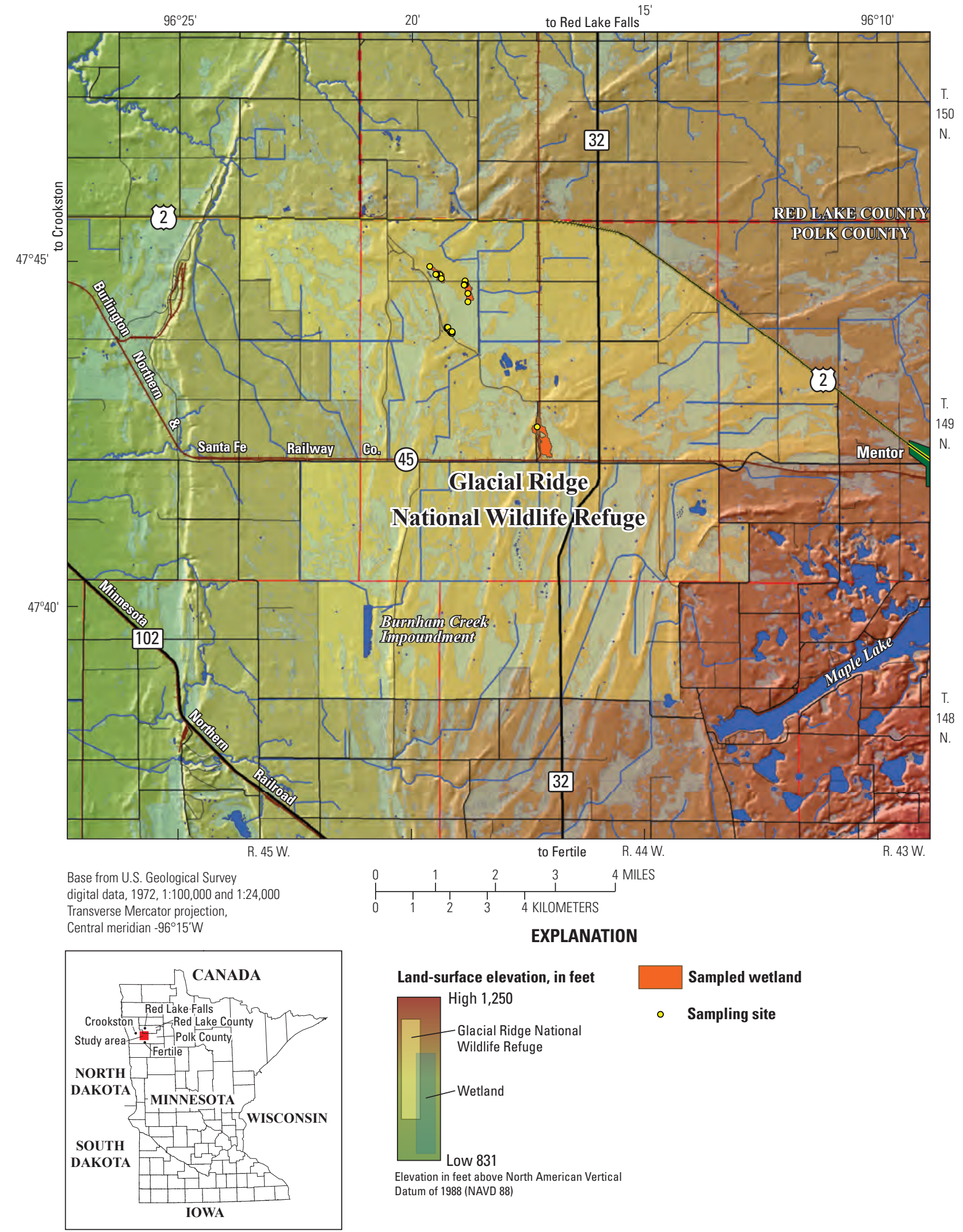

Sampled wetland

Elevation in feet above North American Vertical Datum of 1988 (NAVD 88)

Figure 1. Glacial Ridge National Wildlife Refuge area, northwestern Minnesota. 
One wetland (the control) was to be unrestored during the sampling period and one was to be newly restored. The water samples were to be collected during the open-water period in two eight-sample synoptic samplings plus four two-sample variability samplings. This plan would result in two synoptic samplings of all wetland sites to assess spatial variability within the wetlands. The plan also would result in two sites (one in each wetland) with six samples per year to assess temporal variability. The sediment samples were to be collected in three eight-sample events along a transect from the deepest wetland point to the wetland edge.

Unfortunately, this planned sampling design had to be modified during sample collection for two reasons. First, the wetlands originally chosen to sample often were dry. Three nearby wetlands were substituted when the originals were dry, so samples were collected at a total of five wetlands. Second, all the sampled wetlands started out unrestored, with three being restored at various times during the sampling period. Wetland (hereinafter WL) 17 and WL18 remained unrestored during most of the sampling, serving as control sites (fig. 2). The other three wetlands were restored in 2007 (WL14 and WL15) and 2008 (WL16), during the sample collection period. Table 1 shows a comparison between planned samples and collected samples. Three features of the samples actually collected prevent the first study objective (the comparison of mercury concentrations between restored and unrestored wetlands) from being achieved. First, the number of water samples from restored wetlands was about one-half that from unrestored wetlands (18 and 37 samples, respectively). Second, water samples from both groups did not come from a single wetland as originally planned, increasing variability and making comparison difficult. Finally, no wetland remained completely unrestored or was completely restored during the entire sampling period. WL14 and WL15 were restored early in the sampling period but rarely held enough water to sample. WL16 was not restored until mid-2008, and WL17 was restored in mid-2009. Thus, only objectives 2 and 3 were achieved, and only results related to these objectives are presented in this report.

The distribution of the collected samples required a different analysis strategy than originally envisioned. Three analyses were performed. First, each sample was assigned a restoration status based on whether the wetland was restored before or after the sample was collected. Statistics were compared between the restored and unrestored sample groups. Second, samples collected at an individual site were compared temporally with each other. Finally, the concentrations of constituents were plotted against each other for all samples to look for relations among constituents.

Samples were collected in a way to avoid contamination using standard USGS methods (U.S. Geological Survey, variously dated). The details of sampling and analysis for each set of constituents are shown in table 2. Water samples were collected from about 1 inch below the water surface using precleaned $\mathrm{C}$-flex tubing and a peristaltic pump. Wetland bed-sediment samples were collected with a Teflon scoop at the sediment/water interface. Mercury samples were put into precleaned containers from the USGS Mercury Research Laboratory in Middleton, Wisconsin, according to the laboratory's protocols (U.S. Geological Survey, 2008). Between each sample, the tubing and scoop were cleaned with a nonphosphate detergent, rinsed with tap water, and rinsed with deionized water at the USGS Mounds View or Grand Rapids, Minn., field laboratories.

Wetland water was analyzed for physical properties and concentrations of filtered (dissolved) major ions, filtered (dissolved) and unfiltered (dissolved and particulate) nutrients, dissolved organic carbon, and unfiltered mercury (total and methylmercury). Particulate concentrations were determined by subtracting filtered values from the unfiltered values. Wetland sediment was analyzed for concentrations of total mercury, methylmercury, and loss-on-ignition. Water-quality data collected for this study during the period June 2007September 2009 are available in the USGS National Water Information System (U.S. Geological Survey, 2012) using the site numbers provided in table 3.

Thirteen quality-assurance samples document sampling contamination (five blank water samples) and sample variability (sequential replicate samples, three water and five sediment) for this study. The blank water samples were analyzed for the same suite of constituents as were the environmental water samples (table 2). Blank water, produced by the respective analyzing laboratories and tested to be free of analyzed chemicals (table 2) at the analytical reporting levels, was passed through sampling equipment to fill sample containers in the field, in the same manner as were environmental samples. The three blank sample sets thus collected were analyzed to assess sampling contamination (about 5 percent of the 55 water samples collected). All blank-sample concentrations were lower than laboratory reporting levels with the exceptions of the chemicals listed in table 4 .

The blank-sample results show that sample contamination generally was very low; concentrations in blank samples were one-half to one order of magnitude lower than concentrations in the environmental samples. Because inorganic mercury is a ubiquitous trace contaminant, both in the environment and in acids and other chemicals used in mercury analysis, low-level detections of total mercury in blank water are common (Goldstein and others, 2003; Brigham and others, 2008).

Three water and five sediment replicate samples were collected to assess the degree of reproducibility of chemical concentrations. Each replicate sample was collected sequentially after the environmental sample using the same equipment and sampling technique. Concentration variability measured with replicate samples may come from variability of concentration within the sampled medium itself or from the sampling procedure. Water concentrations were less variable than sediment concentrations, probably reflecting the fact that water is better mixed than sediment. No special effort was taken to reduce variability in sediment samples. One of the purposes for replicate samples was to assess the actual variability in the medium sampled. Many water-replicate 

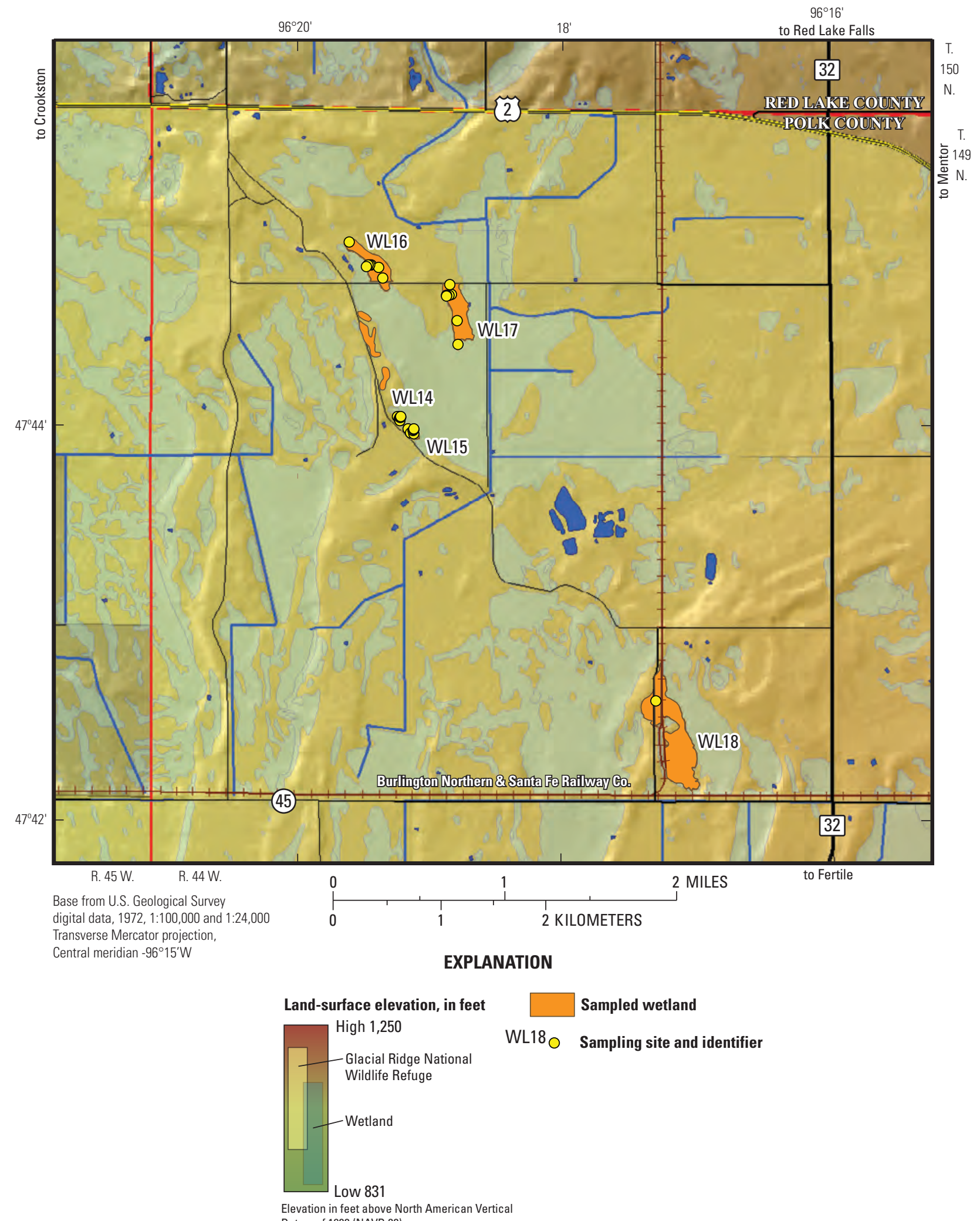

(N)

Figure 2. Sampled wetlands and sampling sites, Glacial Ridge National Wildlife Refuge, northwestern Minnesota, 2007-9. 
Table 1. Comparison of planned sampling design with collected samples, Glacial Ridge National Wildlife Refuge, northwestern Minnesota, 2007-9.

[WL, wetland; shaded cells represent the number of samples collected at the control (unrestored) wetland. WY, water year (12-month period, October 1 through September 30 , and is designated by the calendar year in which it ends); - , zero; na, not applicable]

\begin{tabular}{|c|c|c|c|c|c|c|c|c|c|c|c|c|c|c|c|c|c|c|c|c|c|c|c|c|}
\hline \multicolumn{25}{|c|}{ Planned samples } \\
\hline & \multicolumn{4}{|c|}{ WY 2007} & \multicolumn{6}{|c|}{ WY 2008} & \multicolumn{6}{|c|}{ WY 2009} & \multicolumn{2}{|c|}{ WY 2007} & \multicolumn{2}{|c|}{ WY 2008} & \multicolumn{2}{|c|}{ WY 2009} & \multicolumn{2}{|c|}{ Total } \\
\hline $\begin{array}{c}\text { Wetland } \\
\text { name or } \\
\text { type }\end{array}$ & 导 & 六 & 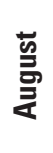 & 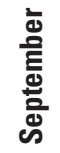 & 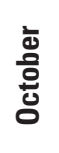 & 홍 & $\sum^{\bar{\pi}}$ & $\stackrel{\Xi}{\Xi}$ & 츸 & 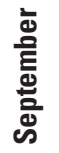 & 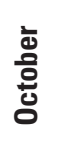 & 竞 & స్ & $\stackrel{\mathscr{E}}{5}$ & 측 & 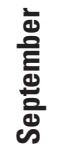 & 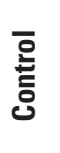 & 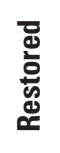 & $\begin{array}{l}\overline{0} \\
\text { 흠 } \\
\text { o }\end{array}$ & 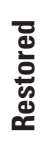 & $\begin{array}{l}\overline{0} \\
\text { 흐 } \\
\text { ơ }\end{array}$ & 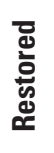 & $\begin{array}{l}\overline{0} \\
\text { 흐 } \\
\text { o }\end{array}$ & 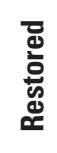 \\
\hline
\end{tabular}

Number of wetland water samples

\begin{tabular}{|c|c|c|c|c|c|c|c|c|c|c|c|c|c|c|c|c|c|c|c|c|c|c|c|c|}
\hline WL14 & 4 & 2 & 4 & 2 & 1 & 4 & 1 & 4 & 1 & 1 & 1 & 4 & 1 & 4 & 1 & 1 & 12 & - & 12 & - & 12 & - & 36 & - \\
\hline WL15 & 4 & 2 & 4 & 2 & 1 & 4 & 1 & 4 & 1 & 1 & 1 & 4 & 1 & 4 & 1 & 1 & - & 12 & - & 12 & - & 12 & - & 36 \\
\hline Control & 4 & 2 & 4 & 2 & 1 & 4 & 1 & 4 & 1 & 1 & 1 & 4 & 1 & 4 & 1 & 1 & 12 & - & 12 & - & 12 & - & 36 & - \\
\hline Restored & 4 & 2 & 4 & 2 & 1 & 4 & 1 & 4 & 1 & 1 & 1 & 4 & 1 & 4 & 1 & 1 & - & 12 & - & 12 & - & 12 & - & 36 \\
\hline \multicolumn{25}{|c|}{ Number of wetland sediment samples } \\
\hline WL14 & 4 & 4 & - & 4 & 4 & - & 4 & - & 4 & - & 4 & - & 4 & - & - & 4 & 12 & - & 12 & - & 12 & - & 36 & - \\
\hline WL15 & 4 & 4 & 一 & 4 & 4 & - & 4 & - & 4 & - & 4 & - & 4 & - & - & 4 & 一 & 12 & - & 12 & - & 12 & - & 36 \\
\hline Control & 4 & 4 & - & 4 & 4 & - & 4 & - & 4 & - & 4 & - & 4 & - & - & 4 & 12 & na & 12 & na & 12 & na & 36 & na \\
\hline Restored & 4 & 4 & 一 & 4 & 4 & 一 & 4 & - & 4 & 一 & 4 & 一 & 4 & 一 & 一 & 4 & na & 12 & na & 12 & na & 12 & na & 36 \\
\hline \multicolumn{25}{|c|}{ Collected samples } \\
\hline & \multicolumn{3}{|c|}{ WY 2007} & & & \multicolumn{5}{|c|}{ WY 2008} & & \multicolumn{5}{|c|}{ WY 2009} & \multicolumn{2}{|c|}{ WY 2007} & \multicolumn{2}{|c|}{ WY 2008} & \multicolumn{2}{|c|}{ WY 2009} & \multicolumn{2}{|c|}{ Total } \\
\hline $\begin{array}{c}\text { Wetland } \\
\text { name or } \\
\text { type }\end{array}$ & $\stackrel{\Xi}{\Xi}$ & 극 & 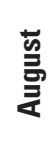 & & & 홍 & స్ & 导 & 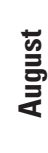 & 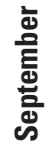 & & $\stackrel{\text { बू }}{\sum}$ & $\stackrel{\Xi}{\Xi}$ & 츨 & 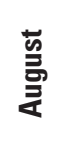 & 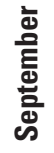 & $\begin{array}{l}\text { 온 } \\
\text { 흥 }\end{array}$ & 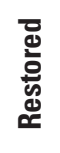 & $\begin{array}{l}\overline{0} \\
\text { 흠 }\end{array}$ & 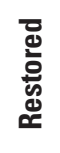 & 온 & 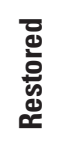 & $\begin{array}{l}\overline{0} \\
\text { 흠 }\end{array}$ & 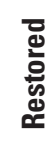 \\
\hline WL14 & 4 & 1 & - & & & - & - & - & - & - & & - & - & - & 1 & - & 4 & 1 & 一 & 4 & - & 1 & 4 & 6 \\
\hline WL15 & 4 & - & - & & & - & - & 4 & - & - & & - & 2 & - & - & - & 4 & - & 一 & - & - & 2 & 4 & 2 \\
\hline WL16 & - & - & - & & & - & - & 1 & - & - & & 4 & 2 & 1 & 1 & - & - & - & 1 & - & - & 8 & 1 & 8 \\
\hline WL17 & - & - & - & & & 4 & 4 & 4 & 1 & 4 & & 4 & 4 & 1 & - & 1 & - & - & 17 & - & 8 & 2 & 25 & 2 \\
\hline WL18 & - & - & - & & & - & - & - & 1 & 1 & & - & - & - & - & 1 & - & - & 2 & - & 1 & - & 3 & - \\
\hline Control & 8 & - & - & & & 4 & 4 & 5 & 2 & 5 & & 4 & 4 & - & - & 1 & 8 & na & 20 & na & 9 & na & 37 & na \\
\hline Restored & - & 1 & - & & & - & - & 4 & - & - & & 4 & 4 & 2 & 2 & 1 & na & 1 & na & 4 & na & 13 & na & 18 \\
\hline \multicolumn{25}{|c|}{ Number of wetland sediment samples } \\
\hline WL14 & 4 & - & - & & & - & - & - & - & - & & - & - & - & - & - & 4 & - & - & - & - & - & 4 & - \\
\hline WL15 & 4 & - & - & & & - & - & - & - & - & & - & 一 & - & - & - & 4 & - & - & - & - & - & 4 & - \\
\hline WL16 & - & - & 4 & & & - & 4 & - & 4 & 4 & & - & - & 4 & 4 & 4 & 4 & - & 4 & 8 & - & 12 & 8 & 20 \\
\hline WL17 & - & - & 4 & & & - & 4 & - & 4 & 4 & & - & - & 4 & 4 & 4 & 4 & - & 12 & - & - & 12 & 16 & 12 \\
\hline WL18 & - & - & - & & & - & 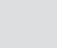 & - & 1 & . & & - & - & - & - & - & - & - & 1 & - & - & - & 1 & - \\
\hline Control & 8 & - & 8 & & & - & 8 & - & 5 & 4 & & - & - & - & - & - & 16 & na & 17 & na & - & na & 33 & na \\
\hline Restored & - & - & - & & & - & - & - & 4 & 4 & & - & - & 8 & 8 & 8 & na & - & na & 8 & na & 24 & na & 32 \\
\hline
\end{tabular}


Table 2. Water-quality sampling details and constituents analyzed, Glacial Ridge National Wildlife Refuge, northwestern Minnesota, 2007-9.

[DOC, dissolved organic compounds; LOI, loss on ignition; $\mathrm{HNO}_{3}$, nitric acid; HCl, hydrochloric acid; NWQL, U.S. Geological Survey National Water-Quality Laboratory; MRL, U.S. Geological Survey Mercury Research Laboratory; NA, not applicable]

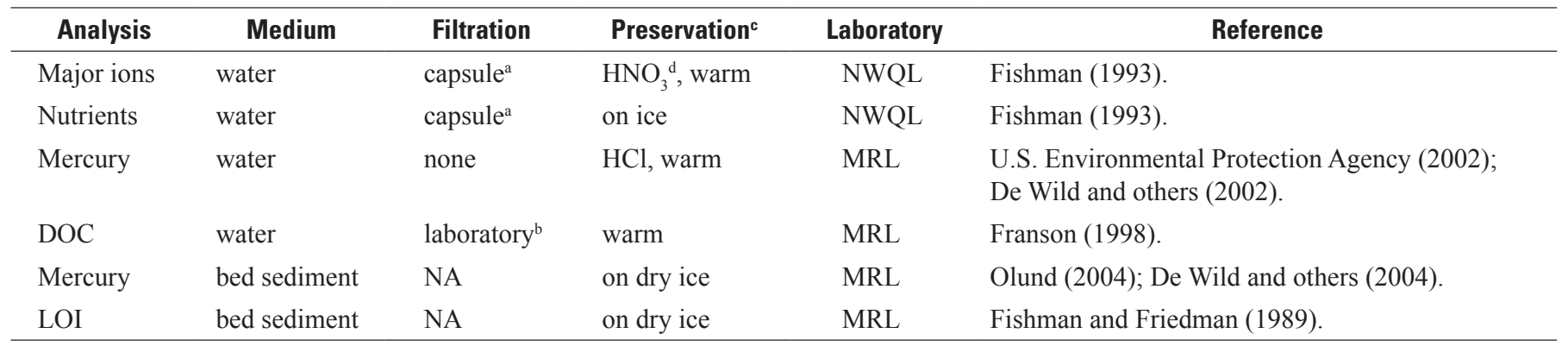

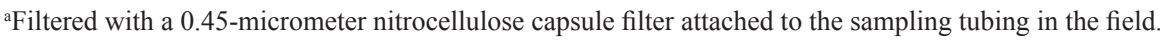

${ }^{b}$ Filtered at the laboratory with a 0.7 -micrometer quartz-fiber filter.

'Preservation and shipping treatment.

${ }^{\mathrm{d}}$ Cation sample preserved with $\mathrm{HNO}_{3}$ to a $\mathrm{pH}$ of less than 2 .

Table 3. Water-quality and sediment-quality data collection sites, Glacial Ridge National Wildlife Refuge, northwestern Minnesota, $2007-9$.

[Water-quality data for these sites are available in the U.S. Geological Survey (USGS) National Water Information System (NWIS, U.S. Geological Survey, 2012); Site naming convention: WLxx, wetland number shown on fig. 2; W, water sample site; S, bed sediment sample site; W/S, water and bed sediment sample site]

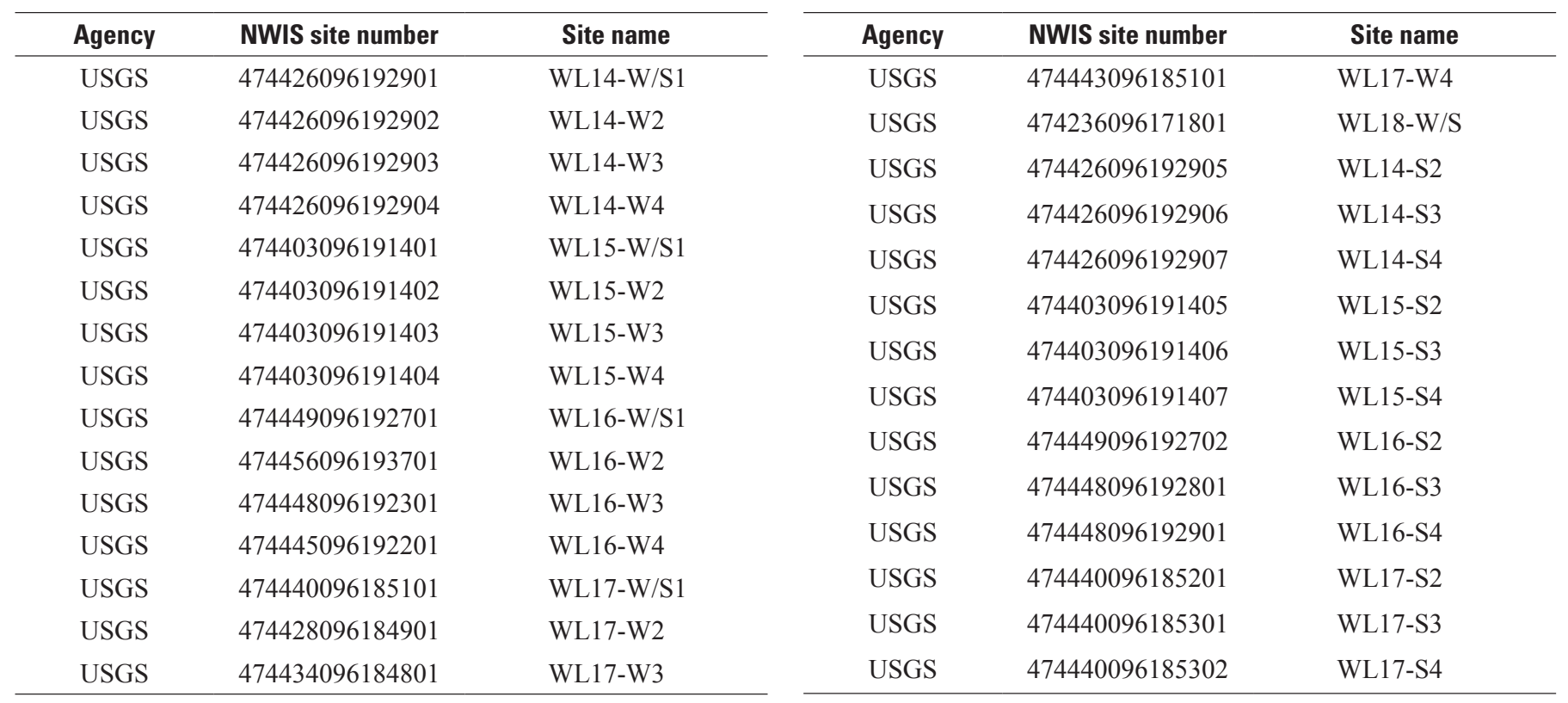


Table 4. Chemicals with blank-sample concentrations greater than the laboratory reporting level.

[ $\mu \mathrm{g} / \mathrm{L}$, microgram per liter; mg/L, milligram per liter; $\mathrm{N}$, nitrogen; $\mathrm{ng} / \mathrm{L}$, nanogram per liter, ND, not determined]

\begin{tabular}{lcccc}
\hline \multicolumn{1}{c}{ Chemical } & $\begin{array}{c}\text { Laboratory reporting } \\
\text { level }\end{array}$ & $\begin{array}{c}\text { Highest blank-water } \\
\text { concentration }\end{array}$ & $\begin{array}{c}\text { Lowest environmental } \\
\text { concentration }\end{array}$ & $\begin{array}{c}\text { Lowest environmental/ } \\
\text { highest blank-water } \\
\text { concentration ratio }\end{array}$ \\
\hline Manganese, dissolved & $0.2-0.4 \mu \mathrm{g} / \mathrm{L}$ & 0.4 & 10 & 25 \\
Ammonia plus organic N, dissolved & $0.1 \mathrm{mg} / \mathrm{L}$ as N & 0.17 & 0.93 & 5 \\
Mercury, total & $0.04 \mathrm{ng} / \mathrm{L}$ & 0.25 & 1.51 & 6 \\
Methylmercury & $0.04 \mathrm{ng} / \mathrm{L}$ & 0.04 & 0.21 & 5 \\
Organic carbon, dissolved & $\mathrm{ND}, \mathrm{mg} / \mathrm{L}$ & 0.9 & 13.3 & 15 \\
\hline
\end{tabular}

concentrations were within 10 relative percent difference $(\mathrm{RPD}=$ absolute value of the concentration of (original - replicate) / [(original + replicate) $/ 2$ multiplied by 100]). Chemical concentrations with RPDs greater than 10 generally were very low, near the laboratory reporting level. Small variability at low concentration produces a high RPD, which is an artifact of the statistic and not a cause for concern. Chemicals in water samples with the high concentrations and high RPDs were dissolved manganese (maximum RPD $=26$ ), unfiltered phosphorus (maximum $\mathrm{RPD}=25$ ), and total mercury (maximum RPD $=43$ ). Maximum sediment mercury and organic matter (loss on ignition) concentration RPDs ranged from 46 to 66, but median RPDs ranged from 18 to 24 .

\section{Wetland Water Quality}

The wetland waters sampled generally were of the calcium/magnesium bicarbonate type, although some samples from WL17 contained as much as 55 percent sulfate in terms of anion milliequivalents. Figure 3 shows the composition and variability of ionic composition of samples, identified by wetland. The higher compositional variability of samples from WL17 probably results from the much greater number of samples from that wetland. WL17 almost always contained water to sample, unlike the other wetlands, which usually dried up in early summer. WL17 may have received more groundwater discharge than other wetlands or simply may have had a larger volume. In either case, as water evaporated from the wetland during the summer, the composition of the water, including its mercury concentrations, may have changed because of simple concentration from evaporation or as biogeochemical processes occurred. A sample from WL17 (the anionic outlier, fig. 3) had the highest chloride concentration of any sample collected (97.3 milligrams per liter, $\mathrm{mg} / \mathrm{L}$ ). The ionic composition of these wetland samples is similar to the composition of samples collected from seven wetlands in the study area during July 2004 (Cowdery and Lorenz, 2008). However, some samples from this current study have much higher sulfate concentrations.
The wetland water was analyzed for a suite of nutrients including ammonia, organic nitrogen, nitrate, nitrite, and phosphorus. The concentration of all forms of nitrogen $(\mathrm{N})$ in the samples ranged from 1.14 to $7.00 \mathrm{mg} / \mathrm{L}$ as N, most of which (86 percent) was in the form of dissolved-organic nitrogen (fig. 4). The median concentration was $2.1 \mathrm{mg} / \mathrm{L}$ as N. Dissolved-nitrate and dissolved-ammonia concentrations were very low. Median and maximum dissolved-nitrate concentrations were less than $0.04 \mathrm{mg} / \mathrm{L}$ as $\mathrm{N}$ and $0.27 \mathrm{mg} / \mathrm{L}$ as $\mathrm{N}$, respectively. Median and maximum dissolved-ammonia concentrations were $0.028 \mathrm{mg} / \mathrm{L}$ as $\mathrm{N}$ and $1.41 \mathrm{mg} / \mathrm{L}$ as N, respectively. The total concentration of all phosphorus $(\mathrm{P})$ in the samples ranged from 0.012 to $1.61 \mathrm{mg} / \mathrm{L}$ as $\mathrm{P}$, with 71 percent of the phosphorus dissolved. The median concentration was $0.334 \mathrm{mg} / \mathrm{L}$ as P. About one-half of the phosphorus was in the form of dissolved orthophosphate (46 percent).

Wetland water also was analyzed for dissolved organic carbon (DOC) because nearly all mercury in water samples is bound to this constituent. Concentrations of suspended solids were low because sampled wetland water was unmoving and clear. Concentrations of DOC in samples ranged from $13.3-41.4 \mathrm{mg} / \mathrm{L}$, with a median concentration of $20.5 \mathrm{mg} / \mathrm{L}$.

\section{Mercury in Wetlands}

Water in wetlands sampled in the Glacial Ridge area had total-mercury and methylmercury concentrations ranging from 1.5 to 20 nanograms per liter (ng/L) and 0.2 to $16 \mathrm{ng} / \mathrm{L}$, respectively (fig. 5). Median total-mercury and methylmercury concentrations in water samples were 7.1 and $2.9 \mathrm{ng} / \mathrm{L}$, respectively. No water sample had concentrations less than the laboratory reporting level of $0.04 \mathrm{ng} / \mathrm{L}$. About one-half of the mercury in wetland water samples was in the form of methylmercury (median of 42 percent) but ranged from 7 to 81 percent. This is a much higher percentage than typical oxic lake and stream waters, in which methylmercury typically comprises about 5 percent of total mercury (although there is considerable range) (Scudder and others, 2009). Comparisons of water samples grouped by restoration status showed no 


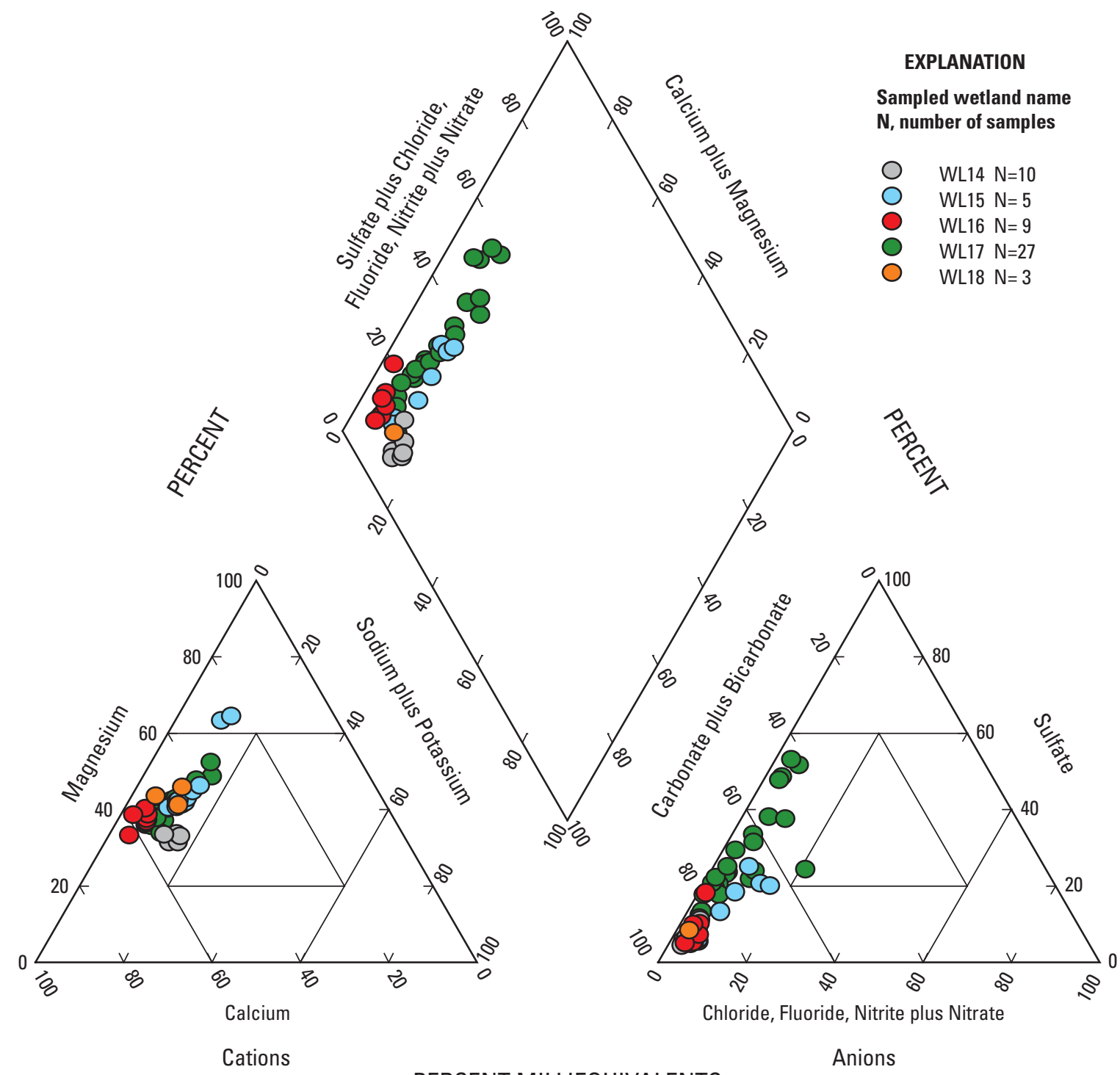

PERCENT MILLIEQUIVALENTS

Figure 3. Wetland water ionic composition, Glacial Ridge National Wildlife Refuge, northwestern Minnesota, 2007-9.

relations among any chemical analyzed. A temporal analysis of water samples at a single site showed no trends among any chemical analyzed. Restoration status relation and temporal trends were also absent from sediment sample results.

Mercury in wetland sediments is of concern because sediment biota are food for other organisms higher in the food chain, and because sediments are the largest reservoir of mercury in a wetland. Wetland sediments sampled in the study area had total-mercury concentrations ranging from 10.6 to 86.2 nanograms per gram $(\mathrm{ng} / \mathrm{g})$; this range is similar to the range observed recently in the Lostwood National Wildlife Refuge (NWR) in northwestern North Dakota (range of
6.77-99.0 ng/g; Sando and others, 2007, location not shown in figures). Methylmercury concentrations in wetland sediments ranged from 0.07 to $7.9 \mathrm{ng} / \mathrm{g}$ (fig. 6), a greater range compared to the Lostwood NWR (range of less than 0.4-4.16 ng/g; Sando and others, 2007). Median total-mercury and methylmercury concentrations in Glacial Ridge wetland sediments were 28.3 and $0.9 \mathrm{ng} / \mathrm{g}$, respectively. No sediment sample had concentrations less than the laboratory reporting levels of $1.4 \mathrm{ng} / \mathrm{g}$ for total mercury and $0.07 \mathrm{ng} / \mathrm{g}$ for methylmercury. About 3 percent of the mercury in wetland sediments was in the form of methylmercury (median) but ranged from 0.3 to 34 percent. 


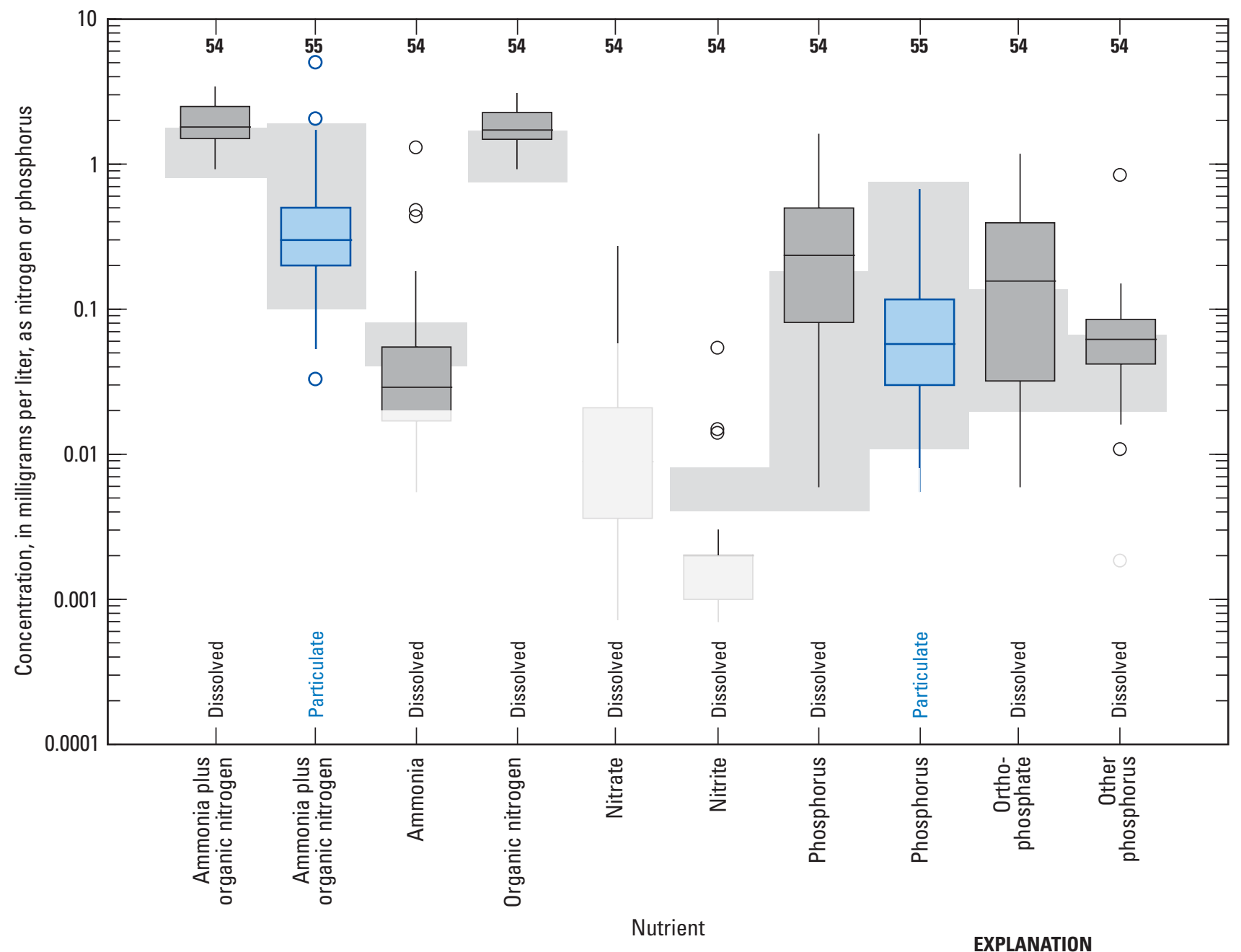

54 - Number of values

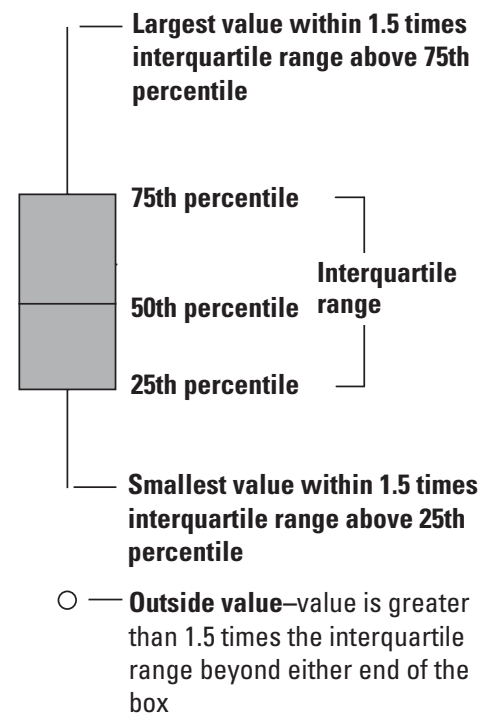

[Lighter box portions, concentration estimated below the laboratory detection limit using regression on order statistics method (Helsel, 2005): medium-grey areas are the range of concentrations from seven wetland samples collected in July 2004 (Cowdery and Lorenz,

Figure 4. Wetland water nutrient composition statistics, Glacial Ridge National Wildlife Refuge, northwestern Minnesota, 2007-9. 
Mercury in Wetlands

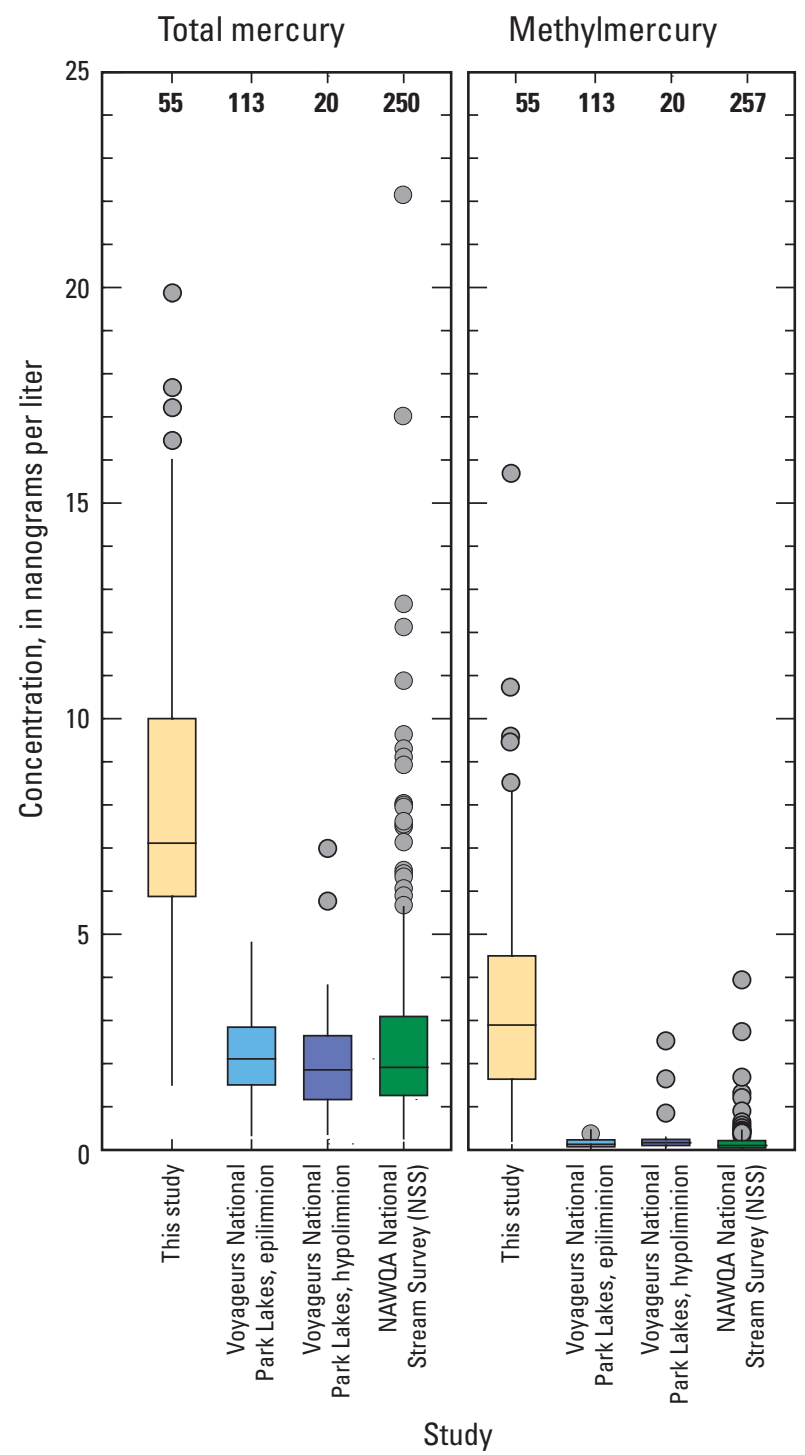

Total mercury

Methylmercury

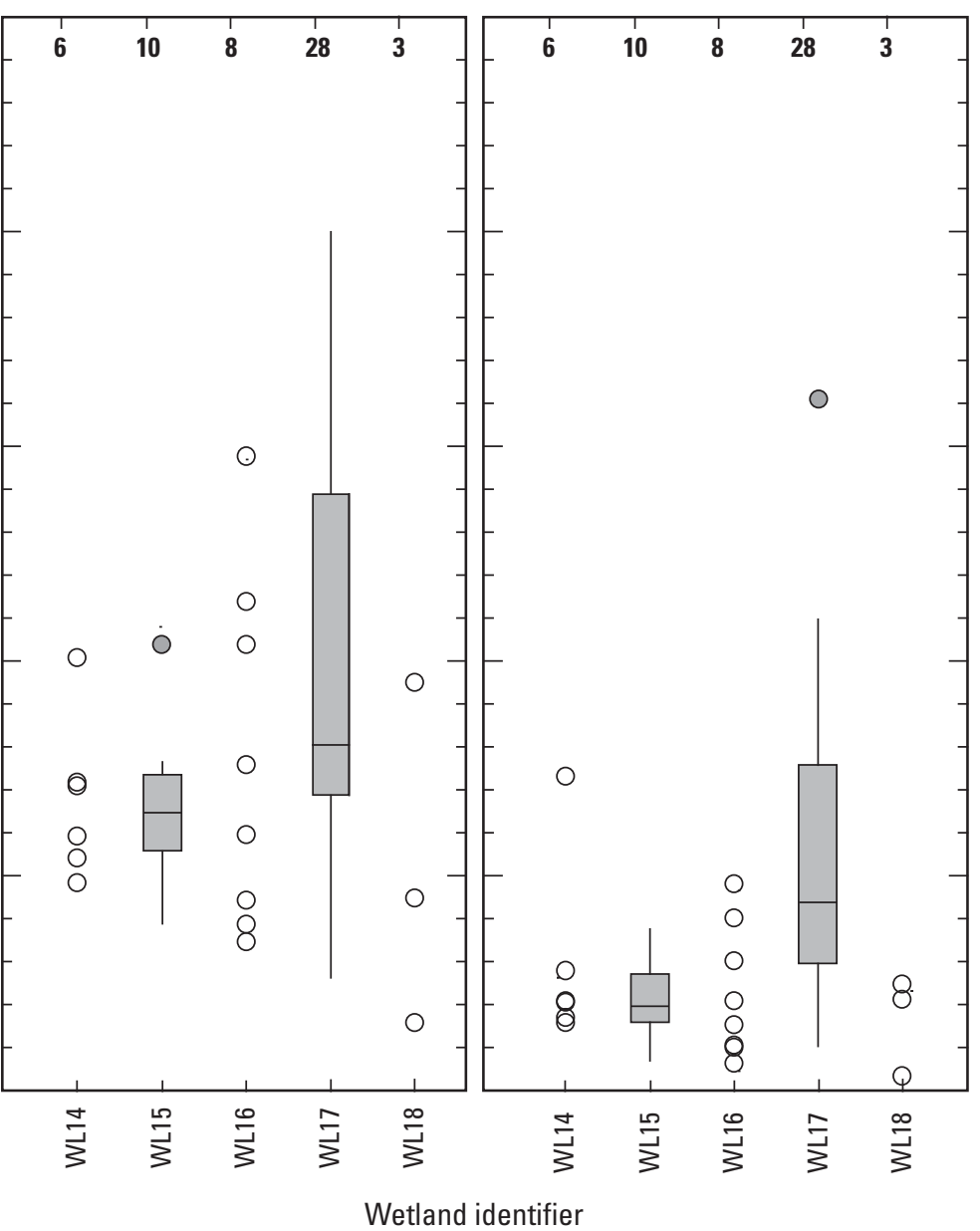

EXPLANATION

3 - Number of samples

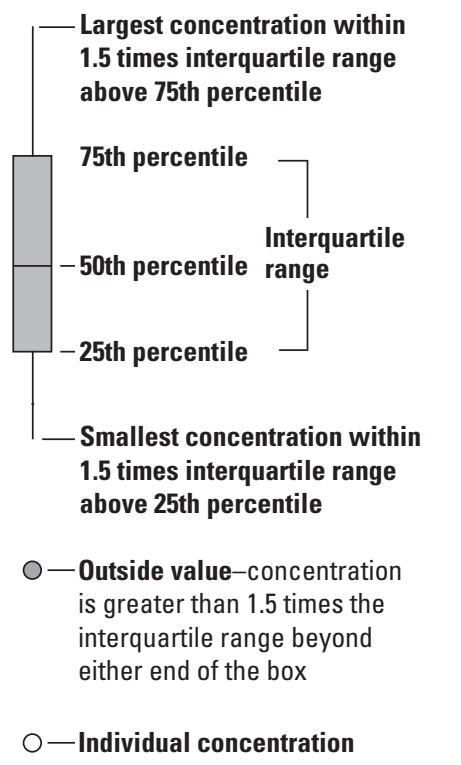

[Voyageurs National Park data (Goldstein and others, 2003) NAWQA NSS, U.S. Geological Survey National Water-Quality Assessment

Figure 5. Wetland water mercury concentrations, Glacial Ridge National Wildlife Refuge, northwestern Minnesota, 2007-9. 
The USGS National Water-Quality Assessment (NAWQA) Program has sampled and compiled streambed sediment mercury concentrations (Scudder and others, 2009). Generally, wetland sediments contain more organic matter than many streambed sediments. The higher organic matter content should promote higher mercury concentrations in wetland sediments because mercury strongly sorbs to organic matter (Zillioux and others, 1993; Skyllberg and others, 2006). Wetland sediment samples from this study had a similar but slightly lower median total-mercury concentration $(28.3 \mathrm{ng} / \mathrm{g})$ than did the NAWQA streambed sediments from unmined basins $(30.3 \mathrm{ng} / \mathrm{g})$ throughout the United States. However, Glacial Ridge area wetland sediment samples had a median methylmercury concentration $(0.9 \mathrm{ng} / \mathrm{g})$ higher than that of the NAWQA samples $(0.5 \mathrm{ng} / \mathrm{g})$. Median loss-on-ignition concentrations (a measure of sediment organic content) in the Glacial Ridge wetland sediment samples (17 percent) were higher than those from the unmined-basin NAWQA samples (4.5 percent). Wetland environments are ideal for the methylation of mercury (St. Louis and others, 1994). These environments contain abundant organic matter, which is a mercury reservoir, and frequently experience anaerobic conditions that encourage the growth of mercury-methylating sulfate- and iron-reducing bacteria. Therefore, although Glacial Ridge area wetland sediment samples contained a typical amount of total mercury, it is reasonable that these sediment samples contained nearly double the methylmercury as did stream sediments throughout the United States.

Sediment-bound contaminants may be of direct toxicological concern to aquatic (benthic) organisms. However, total-mercury concentrations measured in Glacial Ridge wetland sediments are well below the published Probable Effect Concentration of $1,060 \mathrm{ng} / \mathrm{g}$ and also well below the Threshold Effect Concentration of $180 \mathrm{ng} / \mathrm{g}$ (MacDonald and others, 2000). These sediment-quality criteria are consensus-based values, determined from multiple studies of toxicity associated with sediment-bound mercury.

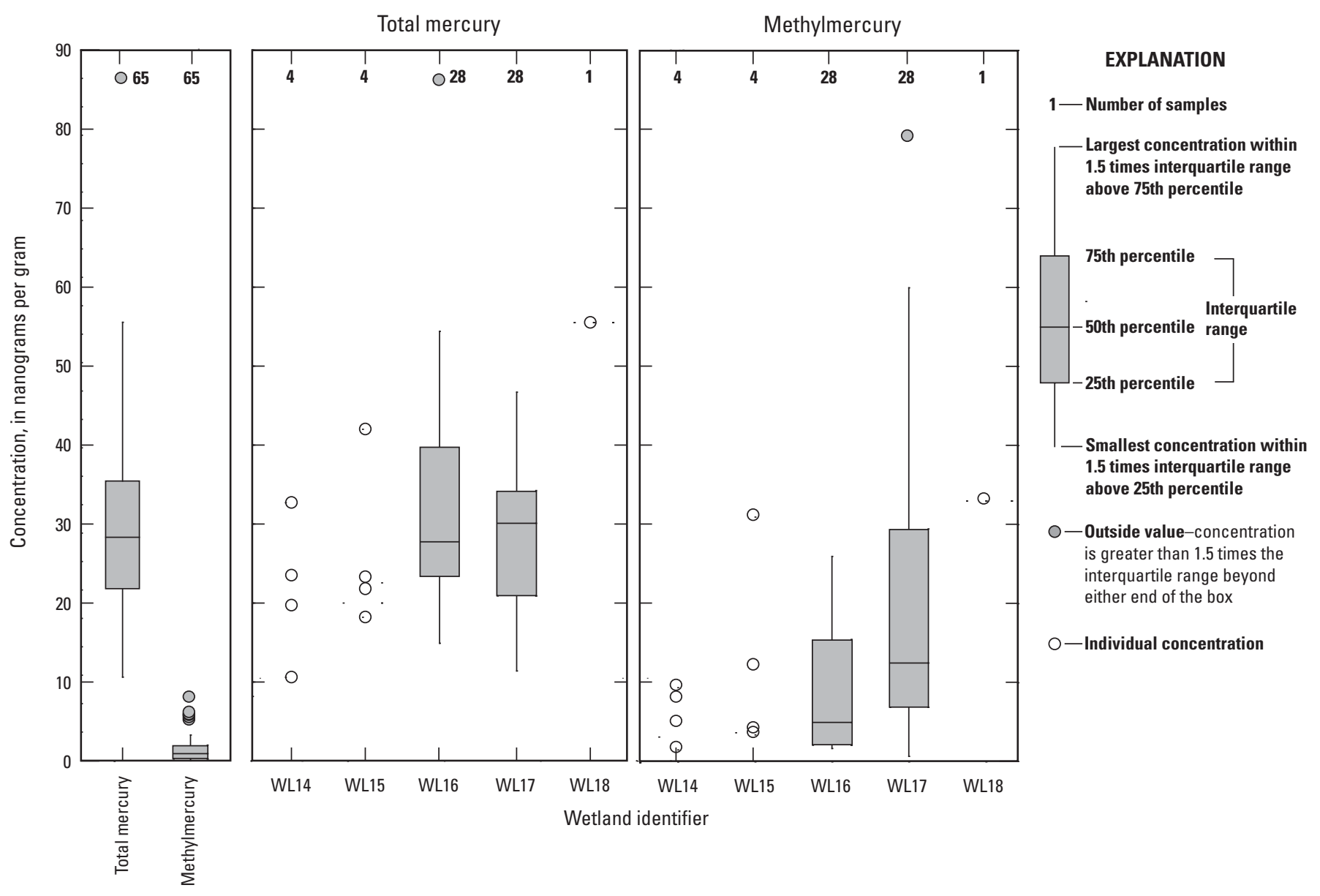

Figure 6. Wetland sediment mercury concentrations, Glacial Ridge National Wildlife Refuge, northwestern Minnesota, 2007-9. 


\section{Methylmercury in Water and Its Relevance to Aquatic Ecosystems}

Methylmercury is a concern because of its toxicity and its large potential to accumulate and biomagnify in aquatic food webs (Wiener and others, 2003). Methylmercury concentrations in algae or periphyton typically are about $10^{3}-10^{6}$ (1,000-1 million) times greater than methylmercury in the water in which the organisms live (Bell and Scudder, 2007; Watras and others, 1998). Methylmercury concentrations tend to increase with each successively higher trophic level, reaching maximum concentrations in organisms at the top of the food web (Wiener and others, 2003). Although biological data were beyond the scope of this study, the high concentrations of methylmercury found in sampled wetlands - particularly in the water column - indicate the potential for substantial methylmercury concentrations in aquatic biota and wildlife that consume those biota.

Methylmercury concentrations in water from the sampled wetlands ranged from 0.21 to $16 \mathrm{ng} / \mathrm{L}$, with a median of $2.9 \mathrm{ng} / \mathrm{L}$ (fig. 5). The maximum concentration measured in these wetlands approaches the highest published water methylmercury concentration in uncontaminated waters of which we are aware $(20 \mathrm{ng} / \mathrm{L}$, measured in a constructed Florida Everglades wetland, Rumbold and Fink, 2006). The upper quartile of water methylmercury concentrations in the Glacial Ridge wetlands (2.9-4.5 ng/L) exceeded most other reported water methylmercury concentrations but was similar to methylmercury concentrations reported for some impoundments and wetlands in northwestern Minnesota and North Dakota. In a survey of wetlands in the Lostwood NWR, unfiltered methylmercury concentrations in surface waters ranged from less than 0.04 to $9.56 \mathrm{ng} / \mathrm{L}$ (Sando and others, 2007). Furthermore, seasonal and semipermanent wetlands tended to have substantially greater methylmercury concentrations than temporary wetlands (inundated briefly) or lakes (inundated year-round most years) (Sando and others, 2007). For unfiltered surfacewater samples from northwestern Minnesota, Brigham and others (2002) reported methylmercury concentrations of $0.056-6.6 \mathrm{ng} / \mathrm{L}$ for a relatively new flood-control impoundment, 0.071-8.36 ng/L for older permanent-pool impoundments in the region, and $0.014-3.67 \mathrm{ng} / \mathrm{L}$ for reference lakes in the region. Sando and others (2003) reported unfiltered methylmercury concentrations of less than $0.04-3.53 \mathrm{ng} / \mathrm{L}$ for 16 lake, wetland, and river sites in the Devils Lake, Sheyenne River, Red River of the North, and Red Lake River Basins of North Dakota and northwestern Minnesota (locations not shown in figures).

Methylmercury concentrations in wetlands sampled for this study were much higher than typical for lakes or flowing streams (fig. 5). A recent NAWQA national stream survey (Bauch and others, 2009; Scudder and others, 2009) reported a range of unfiltered-water methylmercury concentrations of less than 0.01 to $4.11 \mathrm{ng} / \mathrm{L}$ (median of $0.11 \mathrm{ng} / \mathrm{L}$, Bauch and others, 2009). A survey of small lakes in Voyageurs National
Park reported unfiltered methylmercury concentrations in epilimnion water samples of less than $0.03-0.53 \mathrm{ng} / \mathrm{L}$; in low oxygen (less than $1 \mathrm{mg} / \mathrm{L}$ oxygen) hypolimnetic water samples, 0.17-2.69 ng/L unfiltered methylmercury concentrations were reported (Goldstein and others, 2003). It is noteworthy that two of the lakes in Voyageurs National Park with relatively high water methylmercury concentrations have fish (northern pike) with the highest mercury concentrations in the State of Minnesota (Wiener and others, 2006; Minnesota Fish Contaminant Database, Bruce Monson, Minnesota Pollution Control Agency, St. Paul, Minn., written commun., 2012).

The most widely recognized mercury human-health concern is methylmercury exposure through fish consumption. Methylmercury-related fish-consumption advisories are widespread in the Upper Midwest, including many lakes and rivers of Minnesota (Minnesota Department of Health, 2012). In addition to human-health concerns, methylmercury is known to adversely affect wild piscivorous (fish-eating) fish, birds, and mammals. A review by Scheuhammer and others (2007) concludes that laboratory studies have demonstrated that "diets that contained $\mathrm{Hg}$ (as methylmercury) at environmentally realistic concentrations resulted in a range of toxic effects in fish, birds, and mammals, including behavioral, neurochemical, hormonal, and reproductive changes." Scheuhammer and others (2007) further conclude that "limited field-based studies, especially with certain wild piscivorous bird species, e.g., the common loon, corroborated laboratory-based results, demonstrating significant relations between methylmercury exposure and various indicators of methylmercury toxicity, including reproductive impairment." The study area does not contain a fishery, so toxicological concerns related to fish consumption are not directly applicable within the study area. However, the high methylmercury concentrations observed in this study attest to the importance of these kinds of wetlands as methylmercury source areas for downstream lakes and rivers, particularly for those wetlands that contribute surface flow to downstream waters.

In recent years, other (nonfish) food web routes have been recognized as a toxicologically important methylmercury exposure source for wildlife. For example, Hawley and others (2009) demonstrated that tree swallows exposed to mercury, through consumption of both terrestrial and aquatic insects, had compromised immune systems. Cristol and others (2008) reported that several songbirds accumulated high levels of methylmercury through consumption of terrestrial spiders; the spiders may have been exposed to mercury by consuming emergent aquatic insects. A review by Evers and others (2005) indicated that mercury exposure to birds can be approximately predicted by foraging guilds of the birds. A general ranking of low to high mercury exposure for birds is: terrestrial herbivores, aquatic herbivores, terrestrial insectivores, benthivorebivalves (birds that consume clams and other bivalves), benthivore-macroinvertebrates (birds that consume benthic insects and other benthic macroinvertebrates), small piscivores, and large piscivores such as eagles and common loons (Evers and others, 2005). 
No biotic methylmercury concentration data exist in the Glacial Ridge area. The high water methylmercury concentrations, combined with the strong bioaccumulation potential of methylmercury and its known ecotoxicological importance in aquatic food webs and birds that feed in those food webs, indicate a need to assess methylmercury levels and possible ecotoxicological endpoints within these ecosystems. Furthermore, aquatic ecosystem disturbances are known to exacerbate methylmercury concentrations. These disturbances include increased inputs of mercury (such as from atmospheric deposition, Orihel and others, 2007), atmospheric sulfate deposition (Jeremiason and others, 2006), and water-level fluctuations (Snodgrass and others, 2000). Better understanding of factors that control methylmercury production and of methylmercury levels within aquatic food webs in ecosystems of the Glacial Ridge area would enable resource managers to better understand and manage risk to wildlife.

\section{Summary}

The Glacial Ridge National Wildlife Refuge was established in 2004 on land that had undergone extensive wetland and prairie restorations by The Nature Conservancy. About 7,000 acres of drained wetlands were restored to their original hydrologic function and aquatic ecosystem. Land managers in the Glacial Ridge area need to understand the dynamics of mercury methylation in the newly restored wetlands to properly manage wildlife populations. To address this need, the U.S. Geological Survey, in cooperation with the U.S. Fish and Wildlife Service and Red Lake Watershed District, completed a study of mercury in wetlands at Glacial Ridge during 2007-9.

The wetland waters sampled generally were of the calcium/magnesium bicarbonate type, although some samples contained as much as 55 percent sulfate in terms of anion milliequivalents. The total concentration of all nitrogen $(\mathrm{N})$ in the samples ranged from 1.14 to $7.00 \mathrm{mg} / \mathrm{L}$ as $\mathrm{N}$, most of which was in the form of dissolved-organic nitrogen (86 percent). Dissolved-nitrate and dissolved-ammonia concentrations were very low. The total concentration of all phosphorus $(\mathrm{P})$ in the samples ranged from 0.012 to $1.61 \mathrm{mg} / \mathrm{L}$ as $\mathrm{P}$, with 71 percent of the phosphorus dissolved. About one-half of the phosphorus was in the form of dissolved orthophosphorus.

Water in wetlands sampled in the study area had totalmercury and methylmercury concentrations ranging from 1.5 to 20 nanograms per liter (ng/L) and from 0.2 to $16 \mathrm{ng} / \mathrm{L}$, respectively. Median total-mercury and methylmercury concentrations were 7.1 and $2.9 \mathrm{ng} / \mathrm{L}$, respectively. No water sample had concentrations less than the laboratory reporting level of $0.04 \mathrm{ng} / \mathrm{L}$. About one-half of the mercury in wetland water samples was in the form of methylmercury (median of 42 percent) but ranged from 7 to 81 percent.
Study area wetland sediment samples contained a typical amount of total mercury, but these sediment samples contained nearly double the methylmercury of typical stream sediments throughout the United States. The maximum methylmercury concentration in study area wetland water samples approached the highest published water concentration in uncontaminated waters of which we are aware. The upper quartile of water methylmercury concentrations in study area wetland samples ( 2.9 to $4.5 \mathrm{ng} / \mathrm{L}$ ) exceeded most other reported water methylmercury concentrations but was similar to methylmercury concentrations reported for some impoundments and wetlands in northwestern Minnesota and North Dakota. Methylmercury concentrations in sampled wetlands were much higher than typical concentrations in lakes or flowing streams.

The high concentrations of methylmercury found in sampled wetlands indicate the potential for substantial methylmercury concentrations in aquatic biota and wildlife that consume those biota. Although the study area does not contain a fishery, the high methylmercury concentrations observed demonstrate that these wetlands are a methylmercury source for downstream lakes and rivers. In recent years, other food-web routes have been recognized as a toxicologically important source of methylmercury to wildlife.

The high concentrations of water methylmercury, combined with the strong bioaccumulation potential of methylmercury and its known ecotoxicological importance in aquatic food webs and birds that feed in those food webs, indicate a need to assess methylmercury levels and possible ecotoxicological endpoints within these ecosystems. Better understanding of factors that control methylmercury production and of methylmercury levels within aquatic food webs in ecosystems of the Glacial Ridge National Wildlife Refuge would enable resource managers to better understand and manage risk to wildlife.

\section{References}

Bauch, N.J., Chasar, L.C., Scudder, B.C., Moran, P.W., Hitt, K.J., Brigham, M.E., Lutz, M.A., and Wentz, D.A., 2009, Data on mercury in water, streambed sediment, and fish tissue from selected streams across the United States, 19982005: U.S. Geological Survey Data Series 307, 32 p.

Bell, A.H., and Scudder, B.C., 2007, Mercury accumulation in periphyton of eight river ecosystems: Journal of the American Water Resources Association, v. 43, no. 4, p. 1-12.

Bodaly, R.A., and Fudge, R.J.P., 1999, Uptake of mercury by fish in an experimental boreal reservoir: Archives of Environmental Contamination and Toxicology, v. 37, no. 1, p. 103-109. 
Bodaly, R.A., St. Louis, V.L., Paterson, M.J., Fudge, R.J.P., Hall, B.D., Rosenberg, D.M., and Rudd, J.W.M., 1997, Bioaccumulation of mercury in the aquatic food chain in newly flooded areas, in Sigel, A., and Sigel, H., eds., Metal ions in biological systems-Mercury and its effects on environment and biology: New York, Marcel Decker, Inc., p. 259-287.

Brigham, M.E., Duris, J.W., Wentz, D.A., Button, D.T., and Chasar, L.C., 2008, Total mercury, methylmercury, and ancillary water-quality and streamflow data for selected streams in Oregon, Wisconsin, and Florida, 2002-06: U.S. Geological Survey Data Series 341, 11 p.

Brigham, M.E., Krabbenhoft, D.P., Olson, M.L., and DeWild, J.F., 2002, Methylmercury in flood-control impoundments and natural waters of northwestern Minnesota, 1997-99: Water, Air, and Soil Pollution, v. 138, no. 1/4, p. 61-78.

Chasar, L.C., Scudder, B.C., Stewart, A.R., Bell, A.H., and Aiken, G.R., 2009, Mercury cycling in stream ecosystems. 3. Trophic dynamics and methylmercury bioaccumulation: Environmental Science and Technology, v. 43, no. 8, p. 2733-2739.

Compeau, G.C., and Bartha, R., 1985, Sulfate-reducing bacteria-Principal methylators of mercury in anoxic estuarine sediment: Applied and Environmental Microbiology, v. 50, no. 2, p. 498-502.

Cowdery, T.K., and Lorenz, D.L., with Arntson, A.D., 2008, Hydrology prior to wetland and prairie restoration in and around the Glacial Ridge National Wildlife Refuge, northwestern Minnesota, 2002-5: U.S. Geological Survey Scientific Investigations Report 2007-5200, 68 p.

Cristol, D.A., Brasso, R.L., Condon, A.M., Fovargue, R.E., Friedman, S.L., Hallinger, K.K., Monroe, A.P., and White, A.E., 2008, The movement of aquatic mercury through terrestrial food webs: Science, v. 320, no. 5874, p. 335.

De Wild, J.F., Olson, M.L., and Olund, S.D., 2002, Determination of methyl mercury by aqueous phase ethylation, followed by gas chromatographic separation with cold vapor atomic fluorescence detection: U.S.Geological Survey Open-File Report 01-445, 14 p.

De Wild, J.F., Olund, S.D., Olson, M.L., and Tate, M.T., 2004, Methods for the preparation and analysis of solids and suspended solids for methylmercury: U.S. Geological Survey Techniques and Methods, book 5, chap. A7, 13 p.

Evers, D.C., Burgess, N.M., Champoux, L., Hoskins, B., Major, A., Goodale, W.M., Taylor, R.J., Poppenga, R., and Daigle, T., 2005, Patterns and interpretation of mercury exposure in freshwater avian communities in Northeastern North America: Ecotoxicology, v. 14, no. 1-2, p. 193-221.
Fishman, M.J., ed., 1993, Methods of analysis by the U.S. Geological Survey National Water-Quality LaboratoryDetermination of inorganic and organic constituents in water and fluvial sediments: U.S. Geological Survey OpenFile Report 93-125, 217 p.

Fishman, M.J., and Friedman, L.C., eds., 1989, Methods for determination of inorganic substances in water and fluvial sediments ( $3 \mathrm{~d}$ ed.): U.S. Geological Survey Techniques of Water-Resources Investigations, book 5, chap. A1, 545 p.

Franson, M.A.H, ed., 1998, Standard methods for the examination of water and wastewater (20th ed.): Washington D.C., American Public Health Association, p. 50-2-5-22.

Goldstein, R.M., Brigham, M.E., Stuewe, L., and Menheer, M.A., 2003, Mercury data from small lakes in Voyageurs National Park, northern Minnesota, 2000-02: U.S. Geological Survey Open-File Report 03-480, 18 p.

Hawley, D., Hallinger, K., and Cristol, D., 2009, Compromised immune competence in free-living tree swallows exposed to mercury: Ecotoxicology, v. 18, no. 5, p. 499-503.

Hecky, R.E., Ramsey, D.J., Bodaly, R.A., and Strange, N.E., 1991, Increased methylmercury contamination in fish in newly formed freshwater reservoirs: Advances in Mercury Toxicology, p. 33-52.

Heinz, G., Hoffman, D., Klimstra, J., Stebbins, K., Kondrad, S., and Erwin, C., 2009, Species differences in the sensitivity of avian embryos to methylmercury: Archives of Environmental Contamination and Toxicology, v. 56, no. 1, p. 129-138.

Helsel, D.R., 2005, Nondetects and data analysis - Statistics for censored environmental data: Hoboken, N.J., John Wiley and Sons, Inc., 266 p.

Jeremiason, J.D., Engstrom, D.R., Swain, E.B., Nater, E.A., Johnson, B.M., Almendinger, J.E., Monson, B.A., and Kolka, R.K., 2006, Sulfate addition increases methylmercury production in an experimental wetland: Environmental Science and Technology, v. 40, p. 3800-3806.

Kelly, C.A., Rudd, J.W.M., Bodaly, R.A., Roulet, N.P., St. Louis, V.L., Heyes, A., Moore, T.R., Schiff, S., Aravena, R., Scott, K.J., Dyck, B., Harris, R., Warner, B., and Edwards, G., 1997, Increases in fluxes of greenhouse gases and methylmercury following flooding of an experimental reservoir: Environmental Science and Technology, v. 31, no. 5, p. 1334-1344.

Kerin, E.J., Gilmour, C.C., Roden, E., Suzuki, M.T., Coates, J.D., and Mason, R.P., 2006, Mercury methylation by dissimilatory iron-reducing bacteria: Applied and Environmental Microbiology, v. 72, no. 12, p. 7919-7921. 
MacDonald, D.D., Ingersoll, C.G., and Berger, T.A., 2000, Development and evaluation of consensus-based sediment quality guidelines for freshwater ecosystems: Archives of Environmental Contamination and Toxicology, v. 39, p. 20-31.

Minnesota Department of Health, 2012, Fish consumption advice, accessed on August 23, 2012, at http://www.health. state.mn.us/divs/eh/fish/.

Olund, S.D., De Wild, J.F., Olson, M.L., and Tate, M.T., 2004, Methods for the preparation and analysis of solids and suspended solids for total mercury: U.S. Geological Survey Techniques and Methods, book 5, chap. 8A, $15 \mathrm{p}$.

Orihel, D.M., Paterson, M.J., Blanchfield, P.J., Bodaly, R.A., and Hintelmann, H., 2007, Experimental evidence of a linear relationship between inorganic mercury loading and methylmercury accumulation by aquatic biota: Environmental Science and Technology, v. 41, no. 14, p. 4952-4958.

Pickhardt, P.C., Folt, C.L., Chen, C.Y., Klaue, B., and Blum, J.D., 2002, Algal blooms reduce the uptake of toxic methylmercury in freshwater food webs: Proceedings of the National Academy of Sciences, v. 99, no. 7, p. 4419-4423.

Rumbold, D.G., and Fink, L.E., 2006, Extreme spatial variability and unprecedented methylmercury concentrations within a constructed wetland: Environmental Monitoring and Assessment, v. 112, no. 1-3, p. 115-135.

Sandheinrich, M.B., and Wiener, J.G., 2011, Methylmercury in freshwater fish - Recent advances in assessing toxicity of environmentally relevant exposures, in Beyer, W.N., and Meador, J.P., eds., Environmental contaminants in biota: Interpreting tissue concentration ( $2 \mathrm{~d}$ ed.): Boca Raton, Fla., Taylor and Francis, p. 26.

Sando, S.K., Krabbenhoft, D.P., Johnson, K.M., Lundgren, R.F., and Emerson, D.G., 2007, Mercury and methylmercury in water and bottom sediments of wetlands at Lostwood National Wildlife Refuge, North Dakota, 2003-04: U.S. Geological Survey Scientific Investigations Report 2007-5219, 66 p.

Sando, S.K., Wiche, G.J., Lundgren, R.F., and Sether, B.A., 2003, Reconnaissance of mercury in lakes, wetlands, and rivers in the Red River of the North Basin, North Dakota, March through August 2001: U.S. Geological Survey Water-Resources Investigations Report 03-4078, 52 p.
Scheuhammer, A.M., Meyer, M.W., Sandheinrich, M.B., and Murray, M.W., 2007, Effects of environmental methylmercury on the health of wild birds, mammals, and fish: Ambio, v. 36 , no. 1 , p. $12-18$.

Scheuhammer, A.M., Basu, N., Evers, D.C., Heinz, G.H., Sandheinrich, M.B., and Bank, M.S., 2012, Ecotoxicology of mercury in fish and wildlife - recent advances, chapter 11, in Bank, M.S., ed., Mercury in the environmentPattern and process: Berkeley, California, University of California Press, p. 223-238.

Scudder, B.C., Chasar, L.C., Wentz, D.A., Bauch, N.J., Brigham, M.E., Moran, P.W., and Krabbenhoft, D.P., 2009, Mercury in fish, bed sediment, and water from streams across the United States, 1998-2005: U.S. Geological Survey Scientific Investigations Report 2009-5109, 74 p.

Skyllberg, U., Bloom, P.R., Qian, J., Lin, C.-M., and Bleam, W.F., 2006, Complexation of mercury (II) in soil organic matter: EXAFS evidence for linear two-coordination with reduced sulfur groups: Environmental Science and Technology, v. 40, no. 13 , p. $4174-4180$.

Snodgrass, J.W., Jagoe, C.H., Bryan, A.L., Jr., Brant, H.A., and Burger, J., 2000, Effects of trophic status and wetland morphology, hydroperiod, and water chemistry on mercury concentrations in fish: Canadian Journal of Fisheries and Aquatic Sciences, v. 57, no. 1, p. 171-180.

St. Louis, V.L., Rudd, J.W.M., Kelly, C.A., Bodaly, R.A., Paterson, M.J., Beaty, K.G., Hesslein, R.H., Heyes, A., and Majewski, A.R., 2004, The rise and fall of mercury methylation in an experimental reservoir: Environmental Science and Technology, v. 38, p. 1348-1358.

St. Louis, V.L., Rudd, J.W.M., Kelly, C.A., Beaty, K.G., Bloom, N.S., and Flett, R.J., 1994, Importance of wetlands as sources of methylmercury to boreal forest ecosystems: Canadian Journal of Fisheries and Aquatic Sciences, v. 51, no. 5, p. 1065-1076.

Strange, N.E., and Bodaly, R.A., 1999, Mercury in fish in northern Manitoba reservoirs and associated waterbodiesResults from 1998 sampling: Winnipeg, Canada, North/ South Consultants, Inc. and Department of Fisheries and Oceans, $56 \mathrm{p}$.

The Nature Conservancy, 2012, Minnesota Glacial Ridge project, accessed August 22, 2012, at http://www.nature.org/ ourinitiatives/regions/northamerica/unitedstates/minnesota/ placesweprotect/glacial-ridge-project.xml. 
U.S. Environmental Protection Agency, 2002, Method 1631, revision E: Mercury in water by oxidation, purge and trap, and cold vapor atomic fluorescence spectrometry:

U.S. Environmental Protection Agency publication EPA-821-R-02-019, 38 p.

U.S. Geological Survey, 2008, How to collect a sample for the mercury lab: USGS mercury research laboratory, accessed September 2009, at http://wi.water.usgs.gov/mercury-lab/ collecting.html.

U.S. Geological Survey, 2012, Water quality samples for Minnesota: USGS National Water Information System Web Interface, accessed August 21, 2012, at http://nwis. waterdata.usgs.gov/mn/nwis/qwdata.

U.S. Geological Survey, variously dated, National Field Manual for the collection of water-quality data: USGS WaterQuality Information, last accessed in September 2009, at http://water.usgs.gov/owq/FieldManual/.

Watras, C.J., Back, R.C., Halvorsen, S., Hudson, R.J.M., Morrison, K.A., and Wente, S.P., 1998, Bioaccumulation of mercury in pelagic freshwater food webs: Science of the Total Environment, v. 219, no. 2/3, p. 183-208.

Wiener, J.G., Knights, B.C., Sandheinrich, M.B., Jeremiason, J.D., Brigham, M.E., Engstrom, D.R., Woodruff, L.G., Cannon, W.F., and Balogh, S.J., 2006, Mercury in soils, lakes, and fish in Voyageurs National Park (Minnesota) Importance of atmospheric deposition and ecosystem factors: Environmental Science and Technology, v. 40, p. $6261-6268$.

Wiener, J.G., Krabbenhoft, D.P., Heinz, G.H., and Scheuhammer, A.M., 2003, Ecotoxicology of mercury, Chapter 16, in Hoffman, D.J., Rattner, B.A., Burton, G.A., Jr., and Cairns, J., Jr., eds., Handbook of ecotoxicology (2d ed.): Boca Raton, Florida, CRC Press, p. 409-463.

Zillioux, E.J., Porcella, D.B., and Benoit, J.M., 1993, Mercury cycling and effects in freshwater wetland ecosystems: Environmental Toxicology and Chemistry, v. 12, no. 12, p. 2245-2264. 
Publishing support provided by the: Rolla and Lafayette Publishing Service Centers

For more information concerning this publication, contact: Director, USGS Minnesota Water Science Center 2280 Woodale Drive

Mounds View, Minnesota 55112

(763) 783-3100

Or visit the Minnesota Water Science Center Web site at: http://mn.water.usgs.gov/ 

